the Brockenhurst series, not more than one-fifth occur in the Barton clay (Upper Eocene) below. The Hempstead marine fauna has still fewer species in common with the Eocene.

The late Sir Charles Lyell proposed to divide the fluviomarine series into two portions, and to group one with the Eocene and the other with the Miocene. But the inconvenience of breaking up this homogeneous series of beds into two portions must be apparent to every one.

Under these circumstances it is felt by geologists that the fluvio-marine strata of the Hampshire basin must be referred to a division of the Tertiaries distinct alike from the Eocene and the Miocene, and this was admitted by almost every one who took part in the discussion last Wednesday, including Prof. Prestwich and Dr. Duncan.

In the year 1854 , Prof. Beyrich, of Berlin, showed that under the great masses of gravels and drift that cover such large tracts in North Germany, and immediately overlying the great Brown-coal formation of the country, there exist marine beds which contain a fauna distinct alike from the fauna of the Miocene and from that of the Eocene; and strata containing the same fauna have since been discovered in the Netherlands, Switzerland, and other parts of Europe. For the division of the tertiary series which contains this fauna, Beyrich proposed the name of the Oligocene. Whether or not its author was happy in the choice of this name, no one can doubt that he has sufficiently demonstrated the distinct character of the great system of beds to which he applies it.

In 1867 von Koenen and Duncan, from a study of the molluscan and coral fauna of the Brockenhurst beds, respectively, proved that the fuvio-marine strata of the Hampshire basin represents the North German Oligocene; and the justice of this correlation is placed beyond doubt in the memoir by Prof. Judd which has just been rend. He shows that the Headon group and the Brockenhurst series represent the lower Oligocene, while the Bembridge group and the Hempstead series are the equivalents of the lower part of the middle Oligocene, the upper Oligocene not being represented in this country.

That the Oligocene is a very important division of the geological series is shown by the fact that in Eastern Europe (Hungary and Transylvania) strata of this age attain a thickness of between 2,000 and 3,000 feet, and contain valuable beds of coal, while in the neighbourhood of the Alps they are from 10,000 to 12,000 feet thick. It is interesting to find that the lower portion at least of this great formation is represented in our own country, and by strata of such thickness and importance.

\section{A NEW CLASS OF RHIZOPODA}

$A T$ a meeting of the Natural History Society of Jena $A$ the following note was read by Prof. Ernst Haeckel : "Upon the PHÆODARIA, a new Group of Marine Siliceous Rhizopods."

The Phæodaria are a group of large marine Rhizopods, rich in specific forms and remarkable in many respects, which have hitherto been included in the typical Radiolaria (Sphæridea, Discidea, Cyrtidea, Cricoidea), from which they differ as widely as do the Acanthometrina. Till lately very few forms of the Phæodaria were known; these were first observed by me at Messina in 1859 , and described in my monograph of the Radiolaria in 1862, as representatives of three different families-

I. Aulacanthidæx (genus Aulacantha).

2. Aulosphæridæ (genus Aulosphara).

3. Cœlodendridæ (genus Celodendrum).

Besides these, I had described two other forms belonging to this group, namely, Thalassoplancta, which I placed among the Thalassosphæridæ, and Dictyocha, which I placed among the Acanthodesmidæ.

Quite a new light has been thrown upon these interest- ing Rhizopods by the Challenger expedition, which dis covered so many forms of the typical Radiolaria in the depths of the Pacific Ocean, that I have been able to define more than 2,000 new species. Besides these, the explorations of the Challenger have brought to light a number of deep-sea Phæodaria hitherto entirely unknown. The number of species of this group in the surface preparations in the Challenger collection which have been examined by me is not so considerable.

John Murray gave, in 1876 , a short account of some of the most peculiar forms of these new deep-sea Phæodaria, under the name of Challengeridæ (Proceedings of the Royal Society, 1876, vol. xxiv. pp. 471, 535, 536, Pl. 24, Figs. 1-6). He draws particular attention, on the one hand, to the extremely delicate and finely-fenestrated structure of the large siliceous shells, and on the other hand to the constant appearance of masses of blackbrown pigment which are scattered through the sarcode, outside the central capsule.

In the new arrangement of the Radiolaria given by me in 1878 , in my article on the "Protista" (Kosmos, vol. iii.), I placed the hollow-spined siliceous Phæodaria already mentioned in a special order of Radiolaria, under the name of "Pansolenia": "The skeleton consists of single hollow tubes, loosely scattered, or connected in radial or concentric order" ("Protistenreich," p. 102).

This group was described in 1879 by Richard Hertwig, in his work on "The Organisation of the Radiolaria," as a special order of the class under the name of "Tripyleæ," with the following characters:- "Radiolaria Monozoa, with single nuclei ; capsule-membrane double, with one principal and two lateral openings; skeleton siliceous, formed of tubes" (l.c., p. 133, p. 87).

Neither the name "Tripyleæ," given by Hertwig, nor my name "Pansolenia" is applicable to all the Rhizopods which I have now placed in the group Phæodaria, as only a portion of these have the three openings in the double membrane of the central capsule, which ought to characterise the "Tripylea," and in a portion of them only the siliceous skeleton is formed of "hollow tubes" ("Pansolenice"). On the other hand, as Murray first showed, a striking character of all these Rhizopods is the constant presence of large dark-brown pigmented granules, scattered irregularly round the central-capsule, and covering the greater part of its outer surface. In brevity I call this extra-capsular mass of dark pigment the Phæodium (申arós or $\phi a i o i o n s=$ dark brown, dusky). The Phæodella, or large brown granules of the Phæodium are not, as Murray supposed (l.c., p. 536) true pigment cells, as a true cell nucleus cannot be observed in them; and the nature of the peculiar pigment of these pseudo-cells is not precisely known; but the quantity and constancy with which the Phæodium appears in all Phæodaria, while it is wanting in all the typical Radiolaria, gives the Phæodaria a high degree of systematic importance. It seems to me at present that the constant presence of the Phæodium and the peculiarly constructed membrane of the centralcapsule are the only systematically reliable characters which separate all Phæodaria from all other Radiolaria.

The size of the Phæodaria is usually very striking in comparison with that of the other Radiolaria, which they greatly surpass in diameter. The greater number of the
Phæodaria are visible to the naked eye, and many are from $\frac{1}{2} \mathrm{I} \mathrm{mm}$. or more in diameter. The conspicuous central capsule is usually round or spheroidal; it is, however, often egg-shaped or somewhat oval. In many cases it is monaxial, in others dipleuric. Its membrane is very firm and always double, the outer layer very thick, the inner thin. The opening through which the pseudopodia appear has the very peculiar structure accurately described by $\mathrm{R}$. Hertwig (1878, l.c.). Many Phæodaria have only
one such opening (Monopylece), others have two at the opposite poles of the central capsule (Amphipylea); many, perhaps the greater number, have three, one larger 
principal opening and two smaller lateral openings (Tripylea), while others have a larger number of openings regularly or irregularly disposed (Sporopylece). Notwithstanding its peculiar structure and conspicuous size, the central capsule of all Phæodaria, has merely the histological value of a single simple cell. This is shown by the microchemical condition of its protoplasmic contents and the nucleus inclosed within it. This cell-nucleus (described by me in I 862 as the "inner vesicle") is vesicular and of large size, being usually more than half the diameter of the central capsule. It sometimes includes one large nucleolus, sometimes several.

The extra-capsular soft substance of all Phæodaria is distinguished by two characteristic peculiarities-first, by the large quantity of the extra-capsular sarcode, which is more voluminous than the intra-capsular, and secondly by the mass of phæodella or "dark pigment granules" which it contains. The colour of the latter is usually dun-brown or black-brown, often greenish or dun-green. The layer which originates the pseudopodia is very thick and inclosed in a thick jelly, often traversed by spaces through which the ray-like pseudopodia protrude. The Phæodella or peculiar pigment-granules of which the large Phæodium is composed, are, like the Phæodium, of varying form and size. Sometimes the Phæodium envelopes the greater part of the capsule, sometimes only one side of it. The extra-capsular yellow cells which are found in all typical Radiolaria are entirely wanted in the Phæodaria.

The siliceous skeleton is extra-capsular in all Phæodaria and is very peculiar in form and structure. Although the principal types of this group have corresponding representatives among the typical Radiolaria, they are usually easily distinguished from the latter. In a small division only, corresponding to the Thalassicollidæ, the siliceous skeleton is entirely wanting (Phaodinida). All other Phæodaria have a characteristic siliceous skeleton, according to the structure of which I distinguish in the group four orders and ten families.

Order I. PHÆOCYSTIA. - The siliceous skeleton is either entirely wanting or it consists of hollow spines, arranged sometimes irregularly, sometimes regularly, outside the central capsule.

Family I. PHжODINID瓜.-Siliceous skeleton entirely wanting. Genera: Phaodina, Phcoocolla.

Family 2. CANNORHAPHIDA.-The siliceous skeleton consists of numerous separate hollow spines, or portions of hollow network, which, scattered round the periphery of the extra-capsular soft substance, are usually arranged tangentially. Genera: Cannorhaphis, Thallassoplancta, Dictyocha.

Family 3. AUlaCANTHIDA.-The siliceous skeleton consists of hollow radial spines, which spring from the outer surface of the central capsule, and traverse the extracapsular jelly. The outer surface of the jelly is usually covered by a thick mantle of fine hollow siliceous needles, which are arranged tangentially and felted together. Genera: Aulacantha, Aulancora, Aulographium.

II. Order. PHAOGROMIA.-The siliceous skeleton consists of a single fenestrated shell which is of different forms, sometimes round, sometimes egg-shaped, often dipleuric, but always furnished with a large principal opening or mouth (more rarely with several openings). Hollow spines with peculiar pore-areas at their bases are often present.

Family 4. CHALLENGERIDÆ.-The siliceous skeleton consists of a fenestrated shell, uniaxial or dipleuric, often laterally compressed and carinated, often egg-shaped or oval, and furnished with a wide opening at one end of the axis. This mouth is seldom simple, it is usually armed with a hollow tooth, or with one or more, often branched hollow tubes. The fenestrated structure of the siliceous shell resembles most closely that of the diatoms; there is a fine pore in the middle of each of the hexagonal facets (Comp. Murray, I876, l.c., Pl. 24, Figs. I, 2, 4). Genera :
Challengeria, Tuscarora, Gazelletta, Porcupinia, Entocanula, Lithogromia.

Family 5. CASTANELLIDE.-The siliceous skeleton consists of a simple round fenestrated shell, which has in one part of its upper surface a wide opening, of ten surrounded by peculiar processes. The fenestrated shell is usually ornamented with solid or hollow spines. Genera : Castanella, Castanidium, Castanissa, Castanopsis, Castanura.

Family 6. CIRCOPORIDÆ.-The siliceous skeleton consists of a sub-spherical or polyhedral siliceous shell, from which radiate in different directions hollow tubes (simple or branched, often provided with whorls of cilia). The shell has a large opening, as well as scattered porefacets. The pores usually form circles round the bases of the spines. (Comp. Murray, 1876, l.c., Pl. 24, Fig. 5-6). Genera: Circoporus, Circospathis, Circostephanus, Porostephanus, Porospathis.

Order III. PHÆOSPHÆRIA.-The siliceous skeleton consists of numerous hollow tubes which are combined in a peculiar manner into a large, usually round or polyhedral fenestrated body.

Family 7. AULOSPHARIDE.-The siliceous shell is a fenestrated ball or a fenestrated polyhedral body whose lattice work is formed of hollow tubes. Hollow spines usually radiate from the points of connection of the latticework (Comp. Haeckel, "Monogr. der Radiol.," I862, p. 357, Taf. x. xi.). Genera: Aulosphara, Aulodictyum, Auloplegma.

Family 8. CANNOSPHÆRIDÆ.-The siliceous skeleton consists of a uniaxial globular or oval simple bounding shell, which is connected by means of hollow radial rods with a composite outer encrusting shell. The outer shell consists of hollow tubes, which form a wide-meshed latticed sphere; hollow simple or branched radial spines spring from the junctions of the lattice (Comp. Hertwig, l.c., I879, p. 9I, Pl. ix.). Genera : Cannacantha, Cannosphara, Calocantha.

Order IV. PHÆOCONCHIA. - The siliceous skeleton consists of two separate fenestrated shells, like those of a bivalve mollusc. Simple or branched hollow tubes are often found at the junction of the valves.

Family 9. CONCHARIDA.-The siliceous skeleton consists of two semicircular or lenticular fenestrated shells turned each to each with the concavities inwards; the edges of the shells are usually set with rows of teeth, which lock together like the teeth of a bivalve (Comp. Murray, 1876, l.c., Pl. 24, Fig. 3). Genera : Concharium, Conchopsis, Conchidium, Conchocaras.

Family IO. CELODENDRID . - The siliceous skeleton consists of two semicircular or lenticular fenestrated shells with the concave sides turned towards each other. Simple or tree-like branched hollow spines spring from the two opposite poles of the principal axis, or from the centre of the junction of the hemispheres. (Haeckel, "Monogr. d. Rad.," I862, p. 360 ; Taf. xiii., Figs. I-4 ; Taf. xxxii., Figs. I-3.) Genera : Calodendrum, Calothammus, Calodrymus, Calothauma.

Taking a comparative survey of the organisation of the known Phæodaria, we can define the characters of this group of Rhizopoda as follows :-

The Phæodaria are single-celled Rhizopods, whose larger cell-body (the central-capsule) incloses a large nucleus (or inner-vesicle). The cell-membrane is always double, pierced by one or more large openings, through which the intra-capsular protoplasm communicates with the much more abundant extra-capsular protoplasm. In the latter, towards the outside, lies the phæodium, a peculiar thick mass of dark pigment-granules (or phæodella). The whole body is inclosed in a thick gelatinous covering, which is often provided with spaces which the numerous pseudopodia traverse in order to rediate freely beyond its outer surface. With very few exceptions (Phæodinideæ) a well-developed, always extra-capsular 
siliceous skeleton is secreted, which forms, as in the different groups of the typical Radiolaria, very varied and delicate structures, usually radiating outwards in hollow siliceous tubes.

N. M.

\section{NOTES}

THE German Chemical Society in entering upon its thirteenth year has elected as president Prof. H. Kopp, of Heidelberg, who for some time past has devoted himself almost exclusively to the chronicling of the history of chemistry. At the same time Prof. Roscoe, of Manchester, and Prof. Marignac, of Geneva, who was compelled a year since by advanced age to relinquish active professorial duties, were elected to honorary membership. The Society now numbers 2,086, of whom 14 are honorary members and about 200 resident at Berlin. The Berichte of the Society, now certainly the most important chemical periodical of the day, forms for the past year a volume of over 2,550 pages containing over 600 communications. An exhaustive index of the first ten years is now in the press, and will soon be ready. The already bulky dimensions of the Berichte, with its constant yearly increase in size, have forced the council of the Society to propose an increase in the membership fee, which instead of 15 s. shall be raised to 20s. annually. The fact that the Society can cover its ordinary expenses and send post free to its members in all parts of the world a periodical of the size above mentioned for so modest an annual fee, affords an interesting glimpse into the comparative cost of scientific association and activity in Germany and in our own country, where the expenses of membership in most of the scientific societies often exclude those in limited circumstances.

Dr. Joseph LEIDY, Professor of Anatomy in the University of Pennsylvania, at Philadelphia, has just been awarded by the Council of the Society of Natural History, Boston, Mass., the great Walker prize, for the value of his researches in natural history. This prize is given once in five years, at the discretion of the Council, to the naturalist whom it shall decide to have performed the most elaborate and original work during that time. This prize has been awarded but once previously - five years ago -to Prof. Alexander Agassiz, of Cambridge, It is usually the sum of $\$ 500$, but on account of the extraordinary merit of Dr. Leidy's researches the Council increased the sum to $\$ 1,000$. Dr. Leidy was for a long time connected with the Geological Survey of the Territories, and one of his most important memoirs, vol. xii. of the final Reports, has just been issued by the Government. In collecting the materials for the volume, Dr. Leidy spent two seasons in the Western Territories under the auspices of the Survey.

THE following arrangements have just been made at the Royal Institution for the lectures after Easter. Tuesdays :-Prof. Huxley-Two Lectures on Dogs, and the Problems connected with them; Mr. Robert H. Scott, F.R.S.-Four Lectures on Wind and Weather; Mr. John Fiske-Three Lectures on American Political Ideas from the Standpoint of Universal History. Thursdays :-Prof. Tyndall-Six Lectures on Light as a Mode of Motion; Mr. T. W. Khys Davids-Three Lectures on the Sacred Books of the Early Buddhists. Saturdays :-Mr. James Sully-Three Lectures on Art and Vision; Prof. Henry Morley-Five Lectures on the Dramatists before Shakespeare, from the Origin of the English Drama, to the year of the Death of Marlowe (1593). The Friday Evening Meetings will be resumed on April 9-Prof. Huxley on the Coming of Age of the "Origin of Species." Succeeding discourses will probably be given by M. Ernest Renan, Mr. W. H. Pollock, Mr. W. Spottiswoode, Mr. G. J. Romanes, Lord Reay, Mr. H. H. Statham, and Mr. Francis Hueffer.
DR. C. W. Siemens was elected last month a Foreign Member of the Royal Academy of Sciences of Stockholm.

WE are glad to see that a movement has been set on foot for a testimonial to Dr. Farr as a mark of appreciation of the value of his statistical labours. The preliminary list of the committee is headed by the name of the Earl of Derby.

THE death is announced, on February 3, of Chintamanay Ragoonatha Charry, F.R.A.S., Head Assistant in the Madras Observatory for the last seventeen years. Attached to that institution for a period of over thirty-five years, he served in succession, in every grade, under the late Major W. S. Jacob, Col. W. K. Worster, Col. J. F. Tennant, R.E., and the present astronomer, and won the esteem and regard of each, by bis intelligence, assiduity, and attachment to the pursuit he had adopted. His strict honesty and ready skill as an observer, combined with accuracy and speed in computation, and a fair and useful amount of self-acquired mathematical knowledge, rendered him, until disabled by impaired healtb, invaluable in the observatory; and the chief share in the Catalogue of Stars in hand, with the Transit Circle, since 1862 , comprising already over 38,000 separate observations, is die to his personal exertions; besides many other special researches of a nature not of ten undertaken by ordinary assistants in observatories. He contributed several papers to the Royal Astronomical Society of London, and was elected a Fellow in January, 1872. He was twice successfully engaged in observations of total eclipses of the sun; on the first occasion in August, 1868, at Vunpurthy, in the Nizam's Dominions, in independent charge of a branch expedition for the purpose; and on the second, in December, 1871, at Avena hy, in the Coimbatore district. He was the first and only native of India who has yet entered the lists as a diccoverer of new celestial objects, having detected two new variable stars, viz., R. Reticuli in 1867 , and V. Cephei in 1878 . He latterly took great interest in delivering public lectures on astronomy, with a view to enlighten his countrymen upon the subject, and to convince them of the absurdity of their notions in regard to celestial phenomena, by familiar explanations, in simple terms, of the true principles of the science, as opposed to the ignorant superstitions and rough predictions of Hindoo astrologers and empirics of the old school.

The French papers, the Gardeners' Chronicle informs us, announce the death of Dr. Boisduval, to whose labours we owe one of the best treatises on the insects which affect garden plants. Dr. Boisduval was an ardent horticulturist, and a leading man for some time at the Central Horticultural Society of France. He dieci in his eighty-second year.

THE death is announced of Dr. Wilibald Artus, Professor of Philosophy at Jena, on February 7 last, aged seventy years. Also of Dr. Franz Xaver von Hlubek, Professor of Agriculture at the Graz Joanneum, on February Io, aged seventy eight years. In the third week of February also died Herr Adolf Müller, one of the directors of the well-known Geographical Institute of Justus Perthes at Gotha.

A monument to Dr. August Petermann, the well-known geographer, has just been erected at Gotha. The design, which is very tasteful, is by Herr Eelbo, and the work was executed by the eminent sculptor, Herr Deutschmann.

A NUMBER of former pupils of Bernhard von Cotta propose to erect a monument in memory of the deceased geologist, and invite subscriptions for this purpose. The Royal Berg-Acadamie at Freiberg will receive contributions.

DURING Napoleon's rule the number of French astronomical observatories was increased to four, viz., Paris, Toulouse, Marseilles, and the Meudon Physical Observatory of Astronomy. The 